\title{
PENATAAN DESTINASI DAN STRATEGI PROMOSI GUNA MENINGKATKAN JUMLAH WISATAWAN DI KAWASAN WISATA ALAM AIK NYET DI DESA BUWUN SEJATI, KECAMATAN NARMADA
}

Diswandi1), Zikriah2, Intan Febrianti2, Wahyuni Farahin2, Rani Yuliandari2, Lailatul Faradani2, Tina Septikayanti2, Adi Suryadi2, Moesa Maulana Akbar2, M. Arbi Firdous2, M. Ilham Fidatama2,

${ }_{1}$ FEB Universitas Mataram

2 Mahasiswa Universitas Mataram

*Co-Author :Diswandi@unram.ac.id

\begin{abstract}
ABSTRAK. Salah satu destinasi wisata yang menjadi andalan yang ada di Desa Buwun Sejati, Kecamatan Narmada adalah Wisata Alam Aik Nyet. Wisata alam Aik Nyet mengandalkan hutan alam yang di dalamnya terdapat beberapa jenis pohon dengan dominasi pohon mahoni. Selain itu, beberapa obyek wisata yang sudah dikembangkan diantaranya hutan wisata, pemandian, perkemahan, wisata edukasi, wisata kuliner dan wisata water tubing. Namun, tidak cukup hanya dengan mengandalkan potensi alamnya saja, perlu juga dilakukan penataan yang lebih baik lagi. Selain itu, strategi promosi menjadi hal yang sangat penting untuk memperkenalkan Wisata Alam Aik Nyet kepada seluruh masyarakat. Oleh karena itu, dilakukan kegiatan penataan oleh kelompok KKN Universitas Mataram di kawasan wisata Alam Aik Nyet diantaranya: pembenahan dan penambahan fasilitas yang ada di kawasan hutan wisata, pengadaan bak sampah, pembuatan ruang ganti, pembuatan papan nama dan informasi di setiap jenis pohon, pembuatan taman bunga, pembuatan peta dan petunjuk jalan, pengadaan jasa photografi dengan jasa penyewaan kostum, pembuatan paket wisata dan pelatihan kepariwisataan. Sedangkan strategi promosi yang dilakukan untuk mempromosikan Wisata Alam Aik Nyet yakni dengan cara membuat akun media sosial diantaranya Instagram dan Blog.
\end{abstract}

Kata Kunci: Desa Buwun Sejati, Wisata Alam Aik Nyet, Wisata Alam, Desa Wisata

ABSTRACT. One of the mainstay tours in the village of Buwun Sejati, Narmada Sub-District is Aik Nyet Nature Tourism. Aik Nyet nature tourism relies on forests in which several types of trees are exist which is dominated by mahogany trees. In addition, several tourism objects that have been developed include forest tours, baths, campsites, educational tours, culinary tours and water tubing tours. However, only relying on its natural potential its not enough, it is also necessary to do a better arrangement. In addition, the promotion strategy becomes very important to introduce Aik Nyet Nature Tourism to the entire community. Therefore, the structuring activities carried out by the University of Mataram Student's Community Service group in the Aik Nyet tourist area include: improvement and addition of existing facilities in the tourist forest area, procurement of trash bins, making dressing rooms, making trees information boards, making flower gardens, making maps and making maps road directions, procurement of photography services with costume rental services, making tour packages and tourism training. While the promotion strategy undertaken to promote Aik Nyet Nature Tourism is by creating social media accounts including Instagram and Blogs.

Keyword: Buwun Sejati Village, Aik Nyet Nature Tourism, Nature Tourism, Tourism Village 


\section{PENDAHULUAN}

Pariwisata merupakan salah satu kegiatan yang mempunyai peranan yang sangat starategi dalam menunjang pembangunan perekonomian nasional. Menurut Rusman (2004), kegiatan pariwisata telah menjadi salah satu kekuatan yang mampu mempercepat penyatuan dunia dalam integrasi ekonomi dan pergerakan manusia dan lintas daerah bahkan lintas negara. Menurut Undang-Undang No. 9 Tahun 1990 tentang Kepariwisataan Jo Peraturan Pemerintah no 67 Tahun 1996, wisata adalah kegiatan perjalanan atau sebagian dari perjalanan tersebut yang dilakukan secara sukarela serta bersifat sementara untuk menikmati obyek dan daya tarik wisata.

Pariwisata didefinisikan sebagai suatu proses sementara dari seseorang menuju ke tempat lain di luar tempat tinggalnya (Gamal, 2002). Menurut Youti (1991), pariwisata berasal dari dua kata yaitu Pari dan Wisata. Pari dapat diartikan sebagai banyak, berkali-kali, berputar-putar atau lengkap. Sedangkan Wisata dapat diartikan sebagai perjalanan atau bepergian yang dalam hal ini sinonim dengan kata "reveal" dalam bahasa Inggris. Atas dasar itu maka kata "pariwisata" dapat juga diartikan sebagai perjalanan yang dilakukan berkali-kali atau berputar-putar dari satu tempat ketempat yang lain yang dalam bahasa Inggris disebut juga dengan istilah "Tour".

Desa Buwun Sejati terletak di Kecamatan Narmada Kabupaten Lombok Barat. Desa ini merupakan pemekaran dari desa Sesaot dan telah berkembang menjadi desa wisata sejak tahun 2018. Desa buwun sejati memiliki potensi besar dalam menggaet wisatawan. Beberapa potensi yang ada di desa tersebut seperti potensi mata air, sungai, wisata alam hutan, air terjun, bukit, industri tradisional ketak dan masih banyak lagi potensi lainnya yang dapat dikembangkan. Adapun beberapa wisata yang terdapat di desa Buwun Sejati diantaranya: wisata alam Aik Nyet, air terjun Tibu Atas, kolam Bunut Ngengkang, bendungan Buwun Sejati, kebun wisata Buwun Sejati, lesehan Taufik II dan sungai Batu Bedil. Diantara beberapa wisata yang ada di desa buwun sejati, Wisata alam Aik Nyet merupakan obyek wisata yang paling utama.

Wisata alam Aik Nyet terletak di Dusun Aik Nyet Desa Buwun Sejati Kecamatan Narmada, berjarak sekitar $22 \mathrm{~km}$ dari kota Mataram dan dapat ditempuh kendaraan bermotor dengan waktu 45 menit. Sejak tahun 1982 kawasan ini sudah dikembangkan dan dimanfaatkan oleh masyarakat sebagai tempat perkemahan. Seiring berjalannya waktu kawasan hutan tersebut banyak masyarakat memanfaatkannya sebagai area berdagang. Kawasan hutan Aik Nyet memiliki banyak sumber mata air, yang hingga saat ini dikembangkan dan dimanfaatkan oleh masyarakat sebagai pemandian. Sejak tahun 2011, kawasan wisata Aik Nyet dikelola oleh para remaja masjid yang berada di dusun Aik Nyet.

Wisata alam Aik Nyet terdiri dari hutan alam di sebelah timur dan kolam pemandian di sebelah barat. Adapun jalur masuk menuju wisata alam Aik Nyet ada dua yakni loket 1 di sebelah timur dan loket 2 di sebelah barat. Di dalam kawasan Aik Nyet, beberapa obyek wisata yang sudah dikembangkan diantaranya hutan wisata, pemandian, perkemahan, wisata edukasi, wisata kuliner dan wisata water tubing. Wisata alam Aik Nyet mengandalkan hutan alam yang di dalamnya terdapat beberapa jenis pohon salah satunya didominasi oleh pohon mahoni yang banyak berjejer dan tertata rapi. Hal ini yang dapat menjadi daya tarik pengunjung karena sangat indah utuk dijadikan spot foto.

Kawasan Hutan Wisata Alam Aik Nyet terkenal dengan keindahan alamnya. Namun, tidak cukup hanya dengan mengandalkan potensi alamnya saja, akan tetapi diperlukan juga akses-akses informasi (promosi wisata), kenyamanan, kebersihan serta faktor-faktor lainnya seperti tersedianya 
fasilitas di kawasan wisata tersebut. Inilah yang menjadi permasalahan utama yang ditemukan di kawasan wisata alam aik nyet, yakni kurangnya promosi dan kegiatan penataan wisatanya yang kurang maksimal.

Penataan Kawasan Wisata merupakan upaya membangun, memperbaiki, ataupun menciptakan tatanan dan aktivitas wisata yang didukung oleh sarana dan prasarana wisata yang lebih efektif dan efisien di suatu lingkungan tertentu berdasarkan potensi wisata yang dimiliki (Hamzens, 2013). Pengelolaan dan penataan suatu kawasan wisata sangat diperlukan dalam rangka memberikan kenyamanan kepada wisatawan untuk bisa tinggal lebih lama di area wisata dan bagaimana wisatawan membelanjakan uang sebanyak-banyaknya selama melakukan wisata.

Promosi merupakan suatu rancangan untuk memperkenalkan atraksi wisata yang ditawarkan dan cara bagaimana atraksi dikunjungi (Hadinoto, 1996). Promosi merupakan suatu kegiatan menyebarluaskan informasi data, mempengaruhi/ membujuk dan mengingatkan seseorang kepada produk yang ditawarkan (Tjibtono, 2001). Promosi merupakan kegiatan memberitahukan produk atau jasa yang hendak ditawarkan kepada calon konsumen/wisatawan yang dijadikan target pasar. Kegiatan promosi idealnya dilakukan secara bekesinambungan melalui beberapa media yang dianggap efektif dapat menjangkau pasar, baik cetak maupun elektronik, namun pemilihannya sangat tergantung pada target pasar yang hendak dituju (Wolah, 2016).

Berdasarkan latar belakang tersebut, penulis bertujuan untuk memberikan informasi kepada masyarakat lokal maupun mancanegara mengenai wisata Alam Aik Nyet di desa Buwun Sejati yang telah dilakukan penataan melalui media sosial. Outcome yang diharapkan adalah adanya dampak positif terhadap perekonomian, budaya, dan lingkungan di desa Buwun Sejati dan khususnya pada daerah tempat wisata Alam Aik Nyet yakni dusun Aiknyet. Semakin banyak pengunjung yang datang, maka semakin banyak pula pendapatan yang masuk dan hasil pendapatan tersebut dikontribusikan seluruhnya untuk pengembangan desa Buwun Sejati khususnya untuk pengembangan wisatanya.

\section{METODE KEGIATAN}

Kegiatan ini dilaksanakan dengan pendekatan kualitatif, yaitu melalui metode ethnography yang dikemas dalam bentuk Praktek Kuliah Kerja Nyata (KKN) Tematik dibawah lembaga penelitian dan pengabdian kepada masyarakat (LPPM) Universitas Mataram. Metode pengumpulan data pada program ini dengan data primer dan sekunder yang didapatkan dari pihak desa dan survei lapangan. Analisis data menggunakan deskriptif kualitatif.

Kegiatan KKN dilaksanakan oleh penulis di Desa Buwun Sejati selama 45 hari dari tanggal 23 Desember 2019 sampai 6 Februari 2020. Selama kegiatan KKN berlangsung, berbagai kegiatan dilakukan mulai dari pengamatan langsung, wawancara dan diskusi bersama warga masyarakat, aparat pemerintah desa dan kelompok sadar wisata (Pokdarwis) di Desa Buwun Sejati. Selain itu, kerja nyata yang dilakukan untuk menata kawasan hutan wisata alam Aik Nyet yaitu diantaranya pembuatan spot foto, petunjuk jalan dan peta wisata, pembuatan informasi pohon dan lain sebagainya. 


\section{HASIL DAN PEMBAHASAN}

Kegiatan KKN (Kuliah Kerja Nyata) merupakan suatu upaya dari perguruan tinggi dalam rangka melaksanakan salah satu tridarma perguruan tinggi yakni pengabdian kepada masyarakat. Melalui kegiatan KKN yang bertema Pariwisata, mahasiswa dapat membagikan dan mengimplementasikan ilmu pengetahuan yang telah didapakan dibangku perkuliahan kepada masyarakat secara langsung. Selain itu, mahasiswa KKN diharapkan dapat memberikan solusi dari permasalahan yang dihadapi masyarakat khususnya permasalahan mengenai pariwisata yang ada di Kawasan Hutan Wisata Alam Aik Nyet. Salah satu permasalahan yang ada di Kawasan Hutan Wisata Alam Aik Nyet adalah penataan yang kurang maksimal dan kurangnya promosi. Oleh karena itu, beberapa kegiatan penataan yang dilakukan di kawasan hutan wisata alam Aik Nyet yakni: pembenahan dan penambahan fasilitas yang ada di kawasan hutan wisata, pengadaan bak sampah, pembuatan ruang ganti, pembuatan informasi tentang nama pohon beserta deskripsinya, pembuatan taman bunga, pembuatan peta dan petunjuk jalan, pengadaan jasa photografi dengan jasa penyewaan kostum, pembuatan paket wisata dan pelatihan kepariwisataan. Selain itu, strategi yang dilakukan untuk mempromosikan wisata alam Aik Nyet yakni dengan cara membuat akun media sosial berupa Instagram dan Blog.

Wisata Alam Aik Nyet terletak di dusun Aik Nyet desa Buwun Sejati Kecamatan Narmada. Kawasan Hutan Aik Nyet seluas 5.999,2 ha sebelumnya berstatus sebagai HPT (Hutan Produksi Terbatas) dan masyarakat menggunakannya sebagai sumber mata pencaharian. Setelah diubahnya status hutan tersebut menjadi kawasan HL (Hutan Lindung), masyarakat diizinkan untuk mengakses kawasan tersebut dengan ketentuan sampai batas tanaman kopi yang menjadi buffer zone hutan Sesaot. Namun ternyata hal tersebut belum meningkatkan pendapatan masyarakat. Oleh karena itu, melihat banyaknya orang yang berkemah dan banyak potensi mata air yang ada di kawasan tersebut, maka masyarakat mulai memanfaatkannya menjadi kawasan hutan wisata yang lebih dikenal dengan nama Wisata Alam Aik Nyet.

Wisata Alam Aik Nyet merupakan salah satu wisata alam yang menyuguhkan pemandian umum dengan nuansa hutan wisata yang masih terjaga kelestariannya. Selain itu, kondisi hutannya masih sangat alami dan airnya yang dingin dimana sumber mata airnya berasal dari Gunung Rinjani. Namun, pengembangan potensi wisata yang ada di wisata tersebut belum dimanfaatkan secara optimal. Berbagai masalah yang seperti keterbatasan sarana prasarana, sumber daya, sistem tata kelola dan juga dukungan yang kurang merupakan permasalahan utama yang masih belum dapat diatasi. Selain itu, permasalahan lainnya adalah promosi wisata Aik Nyet sangat minim, sehingga wisatawan yang datang tidak terlalu banyak. Seiring berkembangnya zaman dan majunya teknologi, maka kegiatan promosi dilakukan melalui media sosial, karena lebih mudah dan dapat diakses oleh semua masyarakat. Oleh karena itu, kegiatan promosi sangat penting dan dibutuhkan untuk menarik wisatawan.

Penataan dan strategi promosi yang dilakukan oleh kelompok KKN Universitas Mataram merupakan salah satu usaha untuk memajukan pariwisata Aik Nyet dan untuk meningkatkan jumlah wisatawan yang datang. Untuk itu, dalam melakukan penataan dan strategi promosi, kelompok KKN Universitas Mataram bekerjasama dengan Pemerintah Desa Buwun Sejati, kelompok sadar wisata (POKDARWIS) dan pengelola wisata. Beberapa kegiatan penataan dan strategi promosi untuk menarik perhatian wisatawan agar berkunjung ke destinasi wisata Alam Aik Nyet adalah sebagai berikut: 


\section{Pembenahan dan penambahan fasilitas di kawasan hutan wisata Aik Nyet}

Kegiatan Pembenahan merupakan kegiatan membenahi dan memperbaiki fasilitas yang sudah ada namun sudah tidak layak, seperti perbaikan papan-papan tulisan yang sudah rusak. Karena, beberapa papan tulisan yang ada di kawasan hutan wisata sudah pudar bahkan rapuh sehingga perlu diganti dengan yang lebih baik.

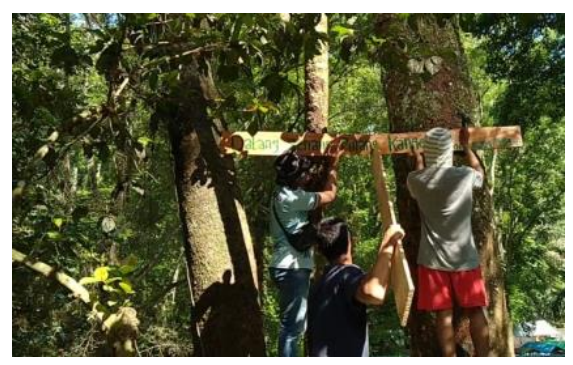

Gambar 1. Perbaikan papan tulisan yang sudah rusak

Adapun penambahan fasilitas merupakan kegiatan pengadaan fasilitas yang belum ada di kawasan wisata. Kegiatan penambahan fasilitas salah satunya adalah pembuatan pegangan tangga menuju sungai. Hal ini ini dilakukan karena jalan menuju ke sungai sangat curam dan licin, sehingga banyak orang yang terpeleset ketika melewatinya. Pegangan tangga terbuat dari ranting pohon dan diikat menggunakan kawat dengan kuat, sehingga dapat memudahkan pengunjung ketika melewati jalan tersebut.

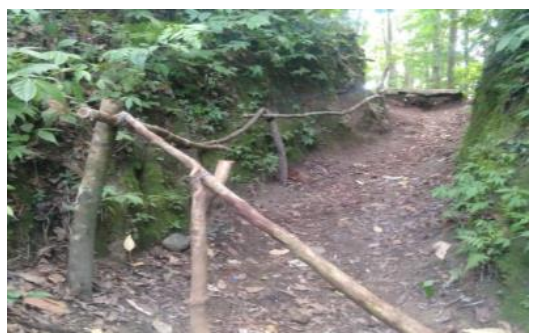

Gambar 2. Pembuatan pegangan tangga menuju sungai

Selain pegangan tangga, fasilitas yang ditambahkan yakni tempat duduk dari kayu. Tempat duduk dari kayu dibuat di dalam kawasan hutan wisata yang bertujuan agar lebih terlihat alami dan terkesan menyatu dengan alam.

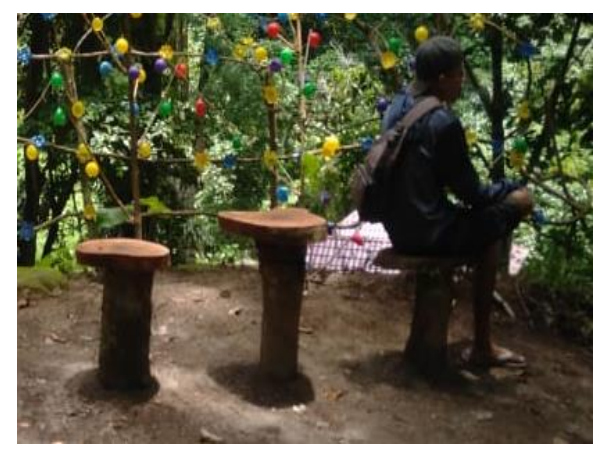

Gambar 3. Tempat duduk dari kayu 


\section{Pembuatan akun sosial media sebagai promosi wisata Aik Nyet}

Pembuatan akun sosial media sebagai promosi wisata Aik Nyet merupakan program kerja utama dari kelompok KKN Universitas Mataram. Perkembangan teknologi, informasi dan komunikasi belakangan ini sangat pesat, sehingga jumlah penggunanya pun semakin meningkat. Media sosial memungkinkan semua orang dapat dengan mudah mengakses informasi. Oleh karena itu, strategi Promosi melalui sosial media sangat mudah dilakukan, karena hanya dengan menggugah foto atau vidio yang bagus, maka akan menarik perhatian para wisatawan untuk berkunjung. Adapun akun sosial media yang dibuat sebagai cara mempromosikan wisata Alam Aik Nyet adalah Instagram dengan nama akun @explore_aiknyet dan Blog dengan alamat www.aiknyet.business.site.
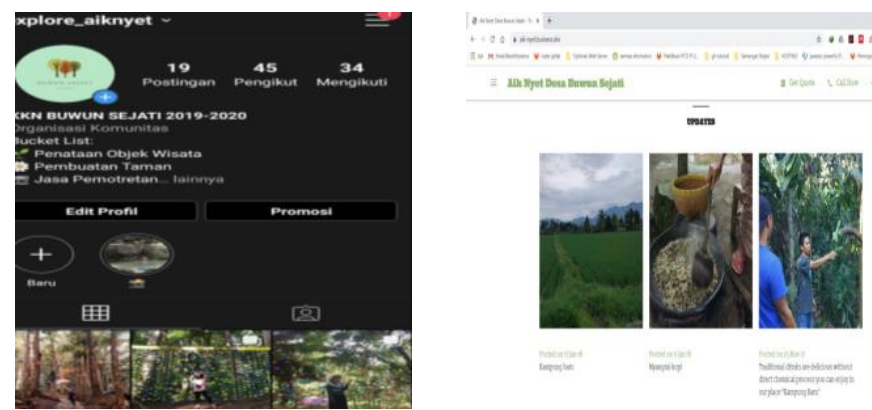

Gambar 4. Instagram dan website wisata Aik Nyet

\section{Pembuatan Ruang Ganti}

Pembuatan ruang ganti merupakan fasilitas yang dibuat untuk memberikan kenyamanan dan kemudahan kepada pengunjung berganti pakaian setelah selesai bermain air di sungai yang ada di Wisata Alam Aik Nyet. Kamar ganti terbuat dari terpal sebagai dindingnya dan kayu sebagai kerangkanya. Lokasi pembuatan ruang ganti berada di pinggir sungai.

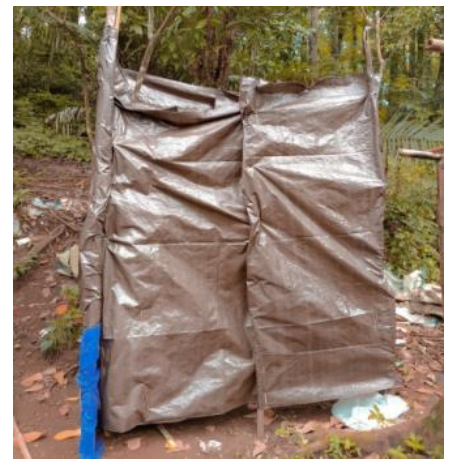

Gambar 5. Pembuatan ruang ganti

\section{Pembuatan petunjuk jalan dan peta wisata Aik Nyet}

Petunjuk jalan dan peta wisata sangat diperlukan oleh pengunjung yang akan berkunjung ke suatu objek wisata. Dengan adanya petunjuk jalan dan peta wisata, maka pengunjung tidak akan kebingungan dan tersesat. Papan petunjuk jalan terbuat dari kayu dan tulisannya dari cat berwarna putih dan dipasang disetiap persimpangan dan jalan masuk menuju wisata. Sedangkan peta wisata di desain kemudian di cetak dan diletakkan di loket 1 dan loket 2. 

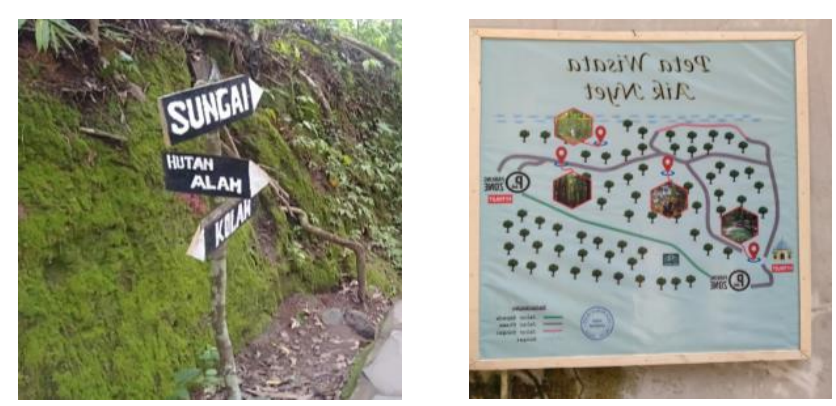

Gambar 6. Petunjuk jalan dan peta wisata Aik Nyet

\section{Pengadaan Tempat Sampah Di Sekitar Lokasi Wisata}

Permasalahan utama di kawasan wisata Alam Aik Nyet adalah banyaknya sampa yang berserakan sehingga tidak enak dipandang. Permasalahan sampah tersebut disebabkan oleh banyak faktor, salah satunya adalah kurangnya kesadaran dari masyarakat dan wisatawan tentang kebersihan sehingga banyak dari mereka yang membuang sampah tidak pada tempatnya. Selain itu, faktor lainnya adalah kurangnya fasilitas tempat pembuangan sampah sangat sedikit sehingga hal tersebut membuat pengunjung kebingungan untuk membuang sampahnya. Oleh karena itu, agar kebersihan dan keindahan wisata Alam Aik Nyet tetap terjaga, maka salah program kerja utama yang dibuat oleh kelompok KKN Universitas Mataram adalah pengadaan bak sampah.

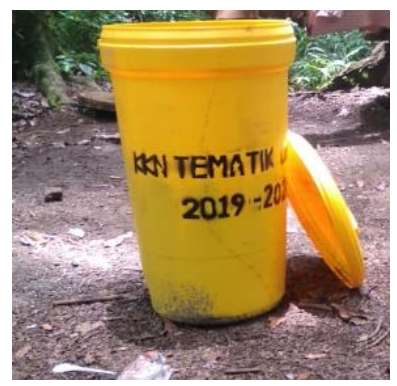

Gambar 7. Bak sampah di kawasan hutan

\section{Pembuatan Taman Bunga Sebagai Objek Wisata}

Pembuatan taman bunga merupakan salah satu program kerja utama yang bertujuan untuk menambah keindahan dan menarik perhatian para wisatawan untuk berkunjung ke Wisata Alam Aik Nyet. Taman bunga yang dibuat ditanami berbagai macam bunga dan juga dibuat dengan semenarik mungkin. Selain itu, untuk menambah keindahan taman, maka diletakkan juga batu yang sudah di cat dengan berbagai warna. Tidak hanya pembuatan taman bunga, namun perawatan bunga yang telah ditanam tetap dilakukan dengan menyiram dan membersihkan setiap pagi dan sore hari agar keindahan taman bunga tetap terjaga. 


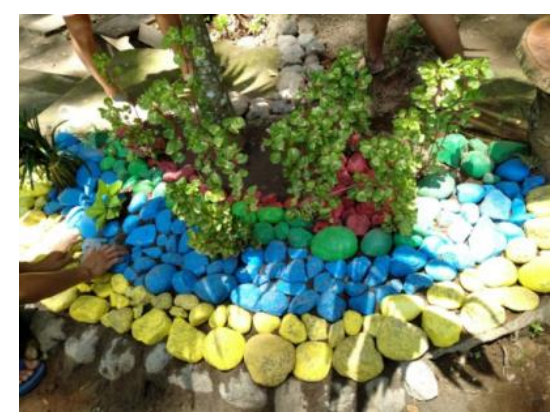

Gambar 8. Pembuatan taman bunga

\section{Pembuatan Papan Nama Dan Deskripsi Pohon}

Pembuatan papan nama dan deskripsi pohon merupakan program kerja utama yang bertujuan untuk memberikan informasi kepada pengunjung berbagai jenis pohon yang ada di kawasan hutan. Selain itu, papan informasi ini juga memuat deskripsi singkat tentang pohon yang bersangkutan. Dengan demikian, pengunjung tidak hanya dapat menikmati keindahan wisata Alam Aik Nyet, tetapi para pengunjung juga mendapatkan pengetahuan mengenai nama-nama latin pohon yang ada disekitar taman. Hal ini dapat menjadi nilai tambah wisata alam Aik Nyet, yakni dapat menjadi wisata edukasi. Papan nama pohon terbuat dari seng dan dicat dengan warna hijau dan tulisannya berwarna putih. Tidak hanya nama latin dan nama lokal saja, papan nama pohon tersebut memuat deskripsi tentang asal dan manfaat dari pohon tersebut.

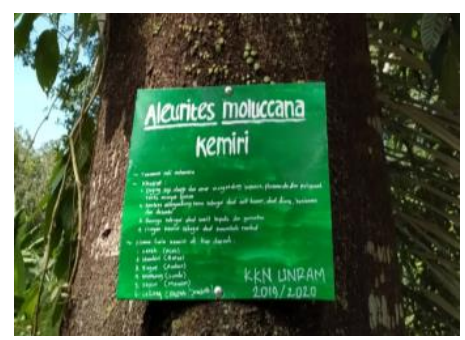

Gambar 9. Penamaan Pohon

\section{Pengadaan Jasa Pemotretan Dengan Fasilitas Penyewaan Kostum}

Pengadaan jasa pemotretan dengan fasilitas penyewaan kostum juga merupakan program kerja utama. Adapun untuk program kerja tersebut, dibutuhkan kamera dan juga spot foto yang bagus dan menarik. Sehingga, dibuat 3 spot foto dikawasan hutan wisata alam Aik Nyet. Adapun spot foto yang dibuat yakni, bola-bola harapan terbuat dari bola besar yang digantung dengan kawat dan benang, kelambu impian yang terbuat dari botol bekas dan pohon pelangi yang terbuat dari bola-bola kecil dan digantung diranting bambu. Adapun jasa penyewaan kostum, kami menyediakan topi, kacamata dan payung yang dapat digunakan ketika berfoto. 


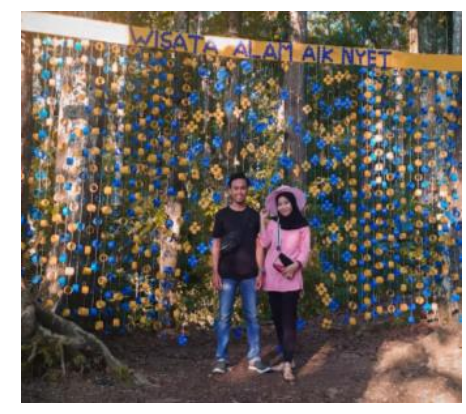

Gambar 10. Salah satu spot foto yang dibuat

\section{Membantu mengajar di SDN 2 Buwun Sejati}

Mengajar di SDN 2 Buwun Sejati merupakan program kerja tambahan. Kegiatan mengajar dilakukan selama seminggu di minggu terakhir KKN. Kelas yang diajar hanya tiga kelas yakni kela 4, 5 dan 6.

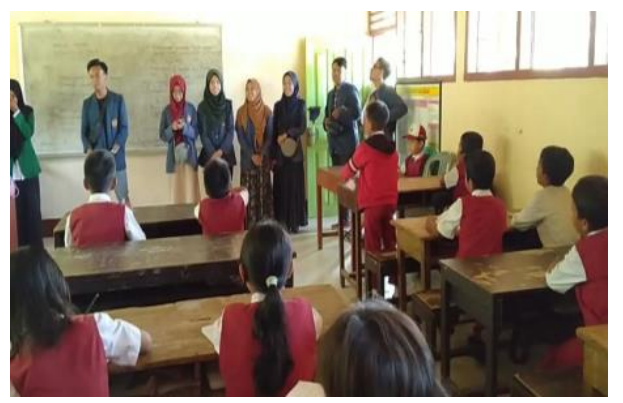

Gambar 11. Mengajar di SDN 2 Buwun Sejati

\section{Pembuatan paket wisata}

Pembuatan paket wisata merupakan salah satu program kerja tambahan. Adapun tujuan pembuatan paket wisata adalah untuk menarik perhatian wisatawan dan juga memberikan kemudahan kepada wisatawan untuk berwisata di wisata Alam Aik Nyet.

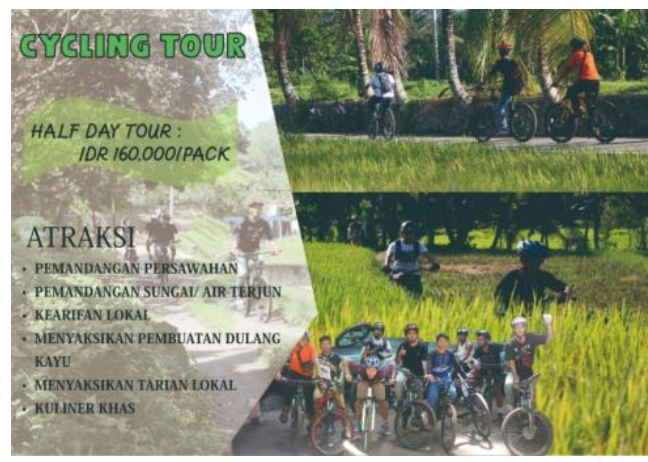

Gambar 12. Paket wisata 


\section{Pelatihan Kepariwisataan Kepada Pengelola Wisata}

Program kerja tambahan lainnya adalah pelatihan kepariwisataan yang sasarannya adalah pengelola wisata Alam Aik Nyet. Tujuan utama pelaksanaan kegiatan pelatihan kepariwisataan tersebut adalah agar para pengelola mendapatkan pengetahuan bagaimana mengelola wisata dan mereka mengerti tanggung jawab masing-masing.

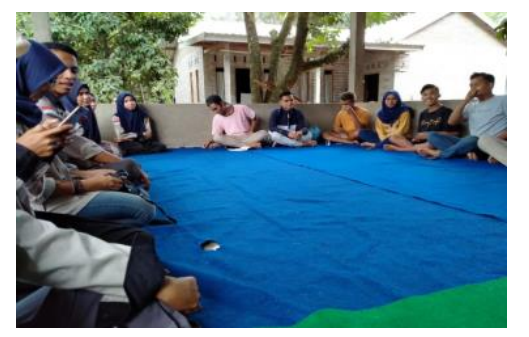

Gambar 13. Pelatihan Kepariwisataan

\section{KESIMPULAN}

Wisata Alam Aik Nyet merupakan wisata utama dan menjadi salah satu wisata andalan yang ada di Desa Buwun Sejati Kecamatan Narmada. Wisata Alam Aik Nyet mengandalkan hutan alamnya yang masih alami dan juga airnya yang jernih, bersih dan dingin yang dimanfaatkan sebagai kolam pemandian. Namun, untuk menggaet wisatawan agar banyak yang datang berkunjung, tidak cukup hanya dengan mengandalkan keindahannya saja. Namun, perlu dilakukan penataan yang lebih baik baik lagi. Selain penataan, hal yang sangat diperlukan adalah strategi promosi agar wisata Alam Aik Nyet dapat lebih dikenal oleh seluruh masyarakat, baik lokal maupun internasional. Karena semakin banyak pengunjung yang berdatangan maka semakin banyak pula pendapatan yang masuk sehingga hasil pendapatan wisata tersebut dapat digunakan untuk mengembangkan Wisata Alam Aik Nyet itu sendiri. Oleh karena itu, kegiatan penataan yang dilakukan oleh kelompok KKN Universitas Mataram di kawasan wisata Alam Aik Nyet adalah: 1) pembenahan dan penambahan fasilitas yang ada di kawasan hutan wisata, 2) pengadaan bak sampah, 3) pembuatan ruang ganti, 4) pembuatan papan nama dan deskripsi pohon, 5) pembuatan taman bunga, 6) pembuatan peta dan petunjuk jalan, 7) pengadaan jasa photografi dengan jasa penyewaan kostum, 8) pembuatan paket wisata dan 9) pelatihan kepariwisataan. Selain itu, strategi yang dilakukan untuk mempromosikan wisata alam Aik Nyet yakni dengan cara membuat akun media sosial diantaranya Instagram dan Blog.

\section{UCAPAN TERIMA KASIH}

Dalam pelaksanaan kuliah Kerja Nyata (KKN) di Desa Buwun Sejati dengan tema Pariwisata, kami banyak mendapatkan pembelajaran, dukungan, bantuan dan bimbingan dari berbagai pihak baik dari pemerintah desa, pengelola wisata dan bahkan masyarakat yang ada di desa Buwun Sejati. Oleh karena itu, kami menyampaikan ucapan terima kasih kepada : 1) Bapak Diswandi,S.E, M.Sc., Ph.D. selaku dosen Pembimbing Lapangan, 2) Bapak Muhidin, S.Ag selaku kepala Desa Buwun Sejati, 3) semua anggota POKDARWIS dan karang taruna, 4) semua pengelola wisata dan 5) kepada seluruh warga masyarakat Desa Buwun Sejati. 


\section{REFERENSI}

Gamal, Suwantoro. 2002. Dasar-Dasar Pariwisata. Yogyakarta: Penerbit Andi.

Hadinoto, Kusudianto. 1996. Perencanaan Pengembangan Destinasi Pariwisata. Jakarta: UI Press.

Hamzens, W.P.S. 2013. Penataan Kawasan Wisata dengan Prinsip Pembangunan Berkelanjutan. E-Journal. 1 (3). 6-11.

Rusman, Heriawan. 2004. Peranan dan Dampak Pariwisata pada Perekonomian Indonesia: Suatu Pendekatan Model I-O dan SAM. Disertasi. Doktoral Institut Pertanian Bogor. Bogor.

Tjibtono, Fandi. 2001. Strategi Pemasaran. Yogyakarta: Andi Offset.

Undang-Undang No. 9 Tahun 1990 tentang Kepariwisataan Yo Peraturan Pemerintah No. 67 Tahun 1996.

Wolah, Ferni Fera Ch. 2016. Peranan Promosi dalam Meningkatkan Kunjungan Wisatawan di Kabupaten Poso. Acta Diurna. 5 (2). 23-40.

Yoeti, Oka A. 1991. Pengantar Ilmu Pariwisata. Bandung: Angkasa. 